\title{
ANALISIS EKONOMI SEKTOR UNGGULAN DI KABUPATEN BANGKA SELATAN TAHUN 2018
}

\author{
Herpin Susanto \\ Herpinsusanto@gmail.com \\ Universitas Bangka Belitung;
}

\begin{abstract}
Abstrak
Dalam suatu pemerintahan maupun daerah tidak akan terlepas dari kegiatan ekonomi dan pembangunan daerah. Untuk meningkatkan pertumbuhan dan pembangunan ekonomi secara opimal maka diperlukan suatu gambaran yang dapat memperlihatkan keterkaitan yang terjadi pada setiap sektor ekonomi, identifikasi sektor unggulan. Tujuan penelitian yaitu untuk menentukan dan menganalisis sektor unggulan di Bangka Selatan dalam memfokuskan pembangunan daerah agar dapat bersaing di perekonomian nasional. penelitian ini menggunakan pendekatan kuantitatif dengan menggunakan metode Loqation Quotient (LQ). Hasil penelitian menyimpulkan bahwa dari 17 sektor yang ada di Kabupaten Bangka Selatan terdapat 2 sektor yang merupakan sektor potensi dengan memiliki nilai rata-rata LQ di atas 1 yaitu sektor pertambangan dan penggalian sebesar $(2,01)$ serta sektor pertanian, kehutanan dan perikanan sebesar $(1,98)$. Hal ini mengidentifikasikan bahwa kedua sektor tersebut merupakan sektor yang dapat dikembangkan dalam rangka meningkatkan Pendapatan Domenstik Regional Bruto di Kabupaten Bangka Selatan
\end{abstract}

Kata Kunci : Ekonomi Regional, Sektor Unggulan

\section{PENDAHULUAN}

Provinsi Kepulauan Bangka Belitung merupakan salah satu provinsi di Indonesia yang terdiri dari beberapa kabupaten, salah satunya Kabupaten Bangka Selatan. Kabupaten Bangka Selatan sendiri dibentuk pada tahun 2003 berdasarkan Undang-undang Nomor 5 Tahun 2003. Dengan luas wilayah 3.607,08 km², Kabupaten Bangka Selatan memiliki 8 kecamatan yaitu Air Gegas, Kepulauan Pongok, Lepar Pongok, Payung, Pulau Besar, Simpang Rimba, Toboali, dan Tukak Sadai. Dalam suatu pemerintahan maupun daerah tidak akan terlepas dari kegiatan ekonomi dan pembangunan daerah. Untuk meningkatkan pertumbuhan dan pembangunan ekonomi secara opimal maka diperlukan suatu gambaran yang dapat memperlihatkan keterkaitan yang terjadi pada setiap sektor ekonomi, identifikasi sektor unggulan. Agar perencanaan yang disusun dapat lebih terarah dan tepat sasaran sehingga dapat memicu pergerakkan ekonomi dan menciptakan pembangunan yang berkelanjutan. Ada berbagai pendekatan alat analisis yang telah banyak digunakan untuk mengidentifikasi komoditas unggulan, dengan menggunakan beberapa kriteria dalam kerangka memenuhi aspek penawaran dan permintaan. Setiap pendekatan memiliki kelebihan dan kelemahannya, sehingga dalam memilih metode analisis untuk menentukan komoditas unggulan ini perlu dilakukan secara hati-hati dan bijaksana. Salah satu pendekatan yang dapat digunakan untuk menginisia komoditas unggulan adalah metode Location Quotient (LQ) (Hendayana, 2016).

Berdasarkan uraian latar belakang maka peneliti tertarik untuk membahas penerapan metode Location quotien (LQ) dalam mengidentifikasi komoditas unggulan. Pembahasan diawali dengan mengemukakan kerangka teoritis, kelebihan dan keterbatasan penggunaan LQ kemudian metodologi yang di dalamnya termasuk tahapan-tahapan penerapan metode LQ serta terakhir aplikasi LQ. Judul yang dibahas dalam penelitian ini adalah "Analisis Potensi Ekonomi Sektor Lapangan Usaha di Kabupaten Bangka Selatan”. 


\section{TINJAUAN PUSTAKA}

\subsection{Potensi Ekonomi}

Ekonomi merupakan salah satu dari sekian banyak ilmu sosial dimana ilmu ini mempelajari aktivitas dari manusia dimana berhubungan erat pada aktivitas produksi, distribusi, dan konsumsi terhadap penggunaan barang dan jasa. Terdapat beberapa definisi ekonomi menurut para ahli yaitu Adam Smith mengartikan ekonomi sebagai penyelidikan mengenai keadaan dan sebab adanya kekayaan Negara. Ekonomi adalah sebagai pengukur tingkat kemajuan suatu negara tersebut, apakan Negara tersebut ekonominya dapat berkembang dengan baik atau keadaan ekonominya semakin buruk.

Potensi dalam kegiatan bidang ekonomi berarti memiliki arti pengertian sesuatu yang dapat dikembangkan atau dapat ditingkatkan pemanfaatan nilainya. Sektor ekonomi potensial atau sektor ungggulan dapat diartikan sebagai sektor perekonomian atau kegiatan usaha yang produktif dikembangkan sebagai potensi pembangunan serta dapat menjadi basis perekonomian suatu wilayah dibanding sektor-sektor lain dalam suatu keterkaitan baik secara langsung maupun tidak langsung (Tjokroamidjojo,1993). Dalam komoditas unggulan adalah barang dan jasa yang di hasilkan masyarakat melalui proses pemilihan dan pengembangan yang memiliki nilai lebih dibandingkan produk lainnya (Alian et.al, 3013). Penelitian mefokuskan tentang pengertian komoditas unggulan melalui proses analisis metode location quatient (LQ).

\subsection{Sektor Lapangan Usaha}

Sektor lapangan usaha merupakan bagian dari Produk Domestik Regional Bruto (PDRB). Produk Domestik Regional Bruto atau PDRB adalah salah satu indikator untuk melihat tingkat percepatan perekonomian suatu daerah, karena PDRB adalah produk barang dan jasa akhir yang dihasilkan dalam suatu wilayah dengan dukungan faktor produksi dalam wilayah tersebut. Lebih rinci lagi ketiga sektor yang masuk dalam komponen PDRB menurut lapangan usaha dikelompokkan dalam dalam 17 lapangan usaha sesuaidenganKlasifikasi Baku Lapangan Usaha Indonesia(KBLI) 2009 dan Kesatuan Buruh Kebangsaan Indonesia (KBKI) 2010 sebagai berikut (Bank Indonesia, 2018):

1. Pertanian, Kehutanan, dan Perikanan

2. Pertambangan dan Penggalian

3. Industri Pengolahan

4. Pengadaan Listrik dan Gas

5. Pengadaan Air, Pengelolaan Sampah, Limbah, dan Daur Ulang

6. Konstruksi

7. Perdagangan Besar dan Eceran; Reparasi Mobil dan Sepeda Motor

8. Transportasi dan Pergudangan

9. Penyediaan Akomodasi dan Makan dan Minum

10. Informasi dan Komunikasi

11. Jasa Keuangan dan Asuransi

12. Real Estate

13. Jasa Perusahaan

14. Administrasi Pemerintahan, Pertahanan, dan Jaminan Sosial Wajib

15. Jasa Pendidikan

16. Jasa Kesehatan dan Kegiatan Lainnya

17. Jasa Lainnya

\subsection{Produk Domestik Regional Bruto (PDRB)}


Produk Domestik Regional Bruto (PDRB) merupakan salah satu indikator penting untuk mengetahui kondisi ekonomi di suatu daerah dalam suatu periode tertentu, baik atas dasar harga berlaku maupun atas dasar harga konstan. PDRB pada dasarnya merupakan jumlah nilai tambah yang dihasilkan oleh seluruh unit usaha dalam suatu daerah tertentu, atau merupakan jumlah nilai barang dan jasa akhir yang dihasilkan oleh seluruh unit ekonomi pada suatu daerah. PDRB atas dasar harga berlaku menggambarkan nilai tambah barang dan jasa yang dihitung menggunakan harga pada tahun berjalan, sedang PDRB atas dasar harga konstan menunjukkan nilai tambah barang dan jasa tersebut yang dihitung menggunakan harga yang berlaku pada satu tahun tertentu sebagai tahun dasar. PDRB menurut harga berlaku digunakan untuk mengetahui kemampuan sumber daya ekonomi, pergeseran, dan struktur ekonomi suatu daerah. Sementara itu, PDRB konstan digunakan untuk mengetahui pertumbuhan ekonomi secara riil dari tahun ke tahun atau pertumbuhan ekonomi yang tidak dipengaruhi oleh faktor harga. PDRB juga dapat digunakan untuk mengetahui perubahan harga dengan menghitung deflator PDRB (perubahan indeks implisit). Indeks harga implisit merupakan rasio antara PDRB menurut harga berlaku dan PDRB menurut harga konstan.(Bank Indonesia, 2018)

\subsection{Penelitian Terdahulu}

a. Penelitian yang dilakukan oleh Hendayana (2016) diperoleh hasil bahwa Berdasarkan data yang diperoleh dari LQ dapat ditarik beberapa informasi penting, diantaranya menyangkut fokusing komoditas unggulan. Jika luas penyebaran komoditas dijadikan patokan penentuan fokus unggulan, maka komoditas yang penyebaran wilayah provinsinya paling luas terpilih sebagai fokus unggulan nasional.

b. Penelitian yang dilakukan oleh Indrawati (2009) menunjukkan bahwa Melalui analisis deskriptif dari lima sektor penghasil output dan nilai tambah diperoleh bahwa dari 8 sektor unggulan ada empat sektor kunci (key sectors) atau sektor yang dapat menjadi sektor unggulan yaitu sektor perdagangan, bangunan, pemerintahan umum \&pertahanan dan angkutan jalan raya khususnya di kota pangkal pinang.

\section{METODE PENELITIAN}

\section{Tempat Dan Waktu}

Kuliah lapangan dilaksanakan di Kantor Badan Pusat Stastistik Kota Pangkalpinang. Lokasi penelitian ini ditentukandengan pertimbangan bahwa BPS merupakan salah satu intansi pemerintah yang menyediakan data-data yang terkait dengan penelitian yang akan di bahas. Kuliah lapangan serta pengumpulan data ini dilakukan selama 30 hari yakni terhitung mulai tanggal 30 Juli - 30 Agustus 2018.

Pengumpulan data dalam kuliah lapang ini dilakukan dengan beberapa metode sebagai berikut :

1. Observasi

Metode ini dimaksudkan melakukan pengamatan secara langsung masalah yang terjadi di lapangan yang sesuai dengan tujuan kuliah lapangan.

2. Studi pustaka

Metode ini digunakan untuk memperoleh data sekunder dengan cara mengumpulkan data dari literatur (pustaka, internet, majalah dan koran) atau pun dari peniliti terdahulu.

Adapun jenis dan sumber data yang digunanakan peneliti ini adalah jenis data kuantitatif yaitu data yang dapat di olah hingga menghasilkan suatu nilai tertentu berupa numerik. Dan sumber data yang digunakan peneliti berupa data sekunder, yaitu data yang dikumpulkan 
oleh oranglain, bukan peneliti itu sendiri. Data ini biasanya berasal dari penelitian lain yang dilakukan oleh lembaga-lembaga atau organisasi seperti BPS dan lain-lain

\section{Metode Pengolahan Data}

Menggunakan metode Loqation Quotient (LQ) menurut Hood (1998), Loqation Quotient adalah suatu alat pengembangan ekonomi yang lebih sederhana dengan segala kelebihan dan keterbatasannya. Teknik LQ banyak digunakan untuk membahas kondisi perekonomian, mengarah pada identifikasi spesialisasi kegiatan perekonomian atau mengukur konsentrasi relatif kegiatan ekonomi untuk mendapatkan gambaran dalam penetapan sektor unggulan sebagai leading sector suatu kegiatan ekonomi (industri). Teknik ini digunakan untuk mengidentifikasi potensi internal yang dimiliki suatu daerah yaitu membaginya menjadi dua golongan yaitu sektor basis dan sektor non basis.Analisis Location Quotient dimaksudkan untuk mengidentifikasi dan merumuskan komposisi dan pergeseran sektor-sektor basis suatu wilayah dengan menggunakan Produk Domestik Regional Bruto (PDRB) sebagai indikator pertumbuhan wilayah (Hendayana, 2016).

Perhitungan LQ menggunakan rumus sebagai (Moineddin, 2003) :

$$
\mathrm{LQ}=\frac{S i / N i}{S / N}
$$

Keterangan

LQ : Nilai Location Quotient

$\mathrm{Si} \quad$ : PDRB Sektor i di Bangka Selatan

S : PDRB total di Bangka Selatan

$\mathrm{Ni} \quad$ : PDRB Sektor i di Propinsi Bangka Belitung

$\mathrm{N} \quad$ : PDRB total di Propinsi Bangka Belitung

Berdasarkan hasil perhitungan LQ dapat dianalisis dan disimpulkan sebagai berikut :

a) Jika LQ lebih besar dari satu (LQ > 1), merupakan sektor basis dan berpotensi untuk ekspor,artinya spesialisasi kota/kabupaten lebih tinggi dari tingkat propinsi.

b) Jika LQ lebih kecil dari satu (LQ< 1 ) merupakan sektor non basis, yaitu sektor yang tingkay spesialisasinya lebih rendah dari tingkat provinsi.

c) Jika LQ sama dengan satu ( $L Q=1)$, berarti tingkat spesialisasi di kabupaten sama dengan tingkat propinsi.

Untuk mengetahui seberapa besar untuk di ekpor ke luar daerah Bangka Selatan dan seberapa besar untuk di konsumsi di bangaka selatan dapat di hitung sebagai berikut :

Ekpor $=\left\{\frac{(r-1)}{r}\right\} 100$

untuk mencari seberapa be: Keterangan: ıdiri di lihat sebagai berikut: consumsi sendiri $=$ Ekpor $-1 \mathrm{r}=$ rata-rata

\section{HASIL DAN PEMBAHASAN}

\section{PDRB Atas Dasar Harga Konstan(ADHK) 2010 Menurut Lapangan Usaha 2010 - 2017}

Penulisan ini mengidentifikasi perkembangan PDRB KabupatenBangka Selatan serta potensi pertumbuhan ekonomi Kabupaten Bangka selatan sehingga sektor-sektor strategis yang potensial dapat di kembangkan untuk meningkatkan PDRB KabupatenBangka selatan. Untuk mengetahui potensi sektor-sektor ekonomi yang 
mendukung PDRB KabupatenBangka Selatan maka digunakan alat analisis LQ yaitu untuk mengetahui apakah sektor ekonomi tersebut termasuk sektor unggulan atau tidak termasuk unggulan untuk meningkatkan PDRB Kabupaten Bangka Selatan. Dalam melakukan analisis potensi ekonomi di sektor lapanagan usaha di Kabupaten Bangka Selatan kita perlu menyiapkan data PDRB ADHK di Kabupaten Bangka Selatan sebagai objek penelitian analisis potensi ekonomi sektor lapangan usaha di Kabupaten Bangka Selatan dan sebagai pembanding dengan PDRB ADHK di Provinsi Kepulauan Bangka Belitung.

Pada tabel 1 dapat dilihat perkembangan PDRB Kabupaten Bangka Selatan Atas Dasar Harga Konstan Tahun 2010 sampai 2017 terlihat bahwa pada kurun waktu 8 tahun terakhir, perkembangan tertinggi berada pada tahun 2017, hal ini terjadi karena peningkatan di sektor pertanian, kehutanan dan kelautan dan juga dari pertambangan dan pengalian. 
Tabel 4.1 PDRB Kabupaten Bangka Selatan Atas Dasar Harga Konstan(ADHK)

\begin{tabular}{|c|c|c|c|c|c|c|c|c|c|}
\hline \multirow{2}{*}{$\begin{array}{l}\mathbf{N} \\
\mathbf{o}\end{array}$} & \multirow{2}{*}{$\begin{array}{l}\text { Kategori } \\
\text { Lapangan } \\
\text { Usaha }\end{array}$} & \multicolumn{8}{|c|}{ Dalam Juta Rupiah } \\
\hline & & 2010 & 2011 & 2012 & 2013 & 2014 & 2015 & 2016 & 2017 \\
\hline 1 & $\begin{array}{l}\text { Pertanian, } \\
\text { Kehutanan, } \\
\text { dan Perikanan }\end{array}$ & $\begin{array}{c}1.404 . \\
626\end{array}$ & $\begin{array}{c}1.511 .6 \\
25\end{array}$ & $\begin{array}{c}1.668 .3 \\
27\end{array}$ & $\begin{array}{c}1.780 .7 \\
18\end{array}$ & $\begin{array}{c}1.849 .6 \\
14\end{array}$ & $\begin{array}{c}1.979 .8 \\
28\end{array}$ & $\begin{array}{c}2.059 .3 \\
01\end{array}$ & $\begin{array}{l}2.061 .0 \\
86\end{array}$ \\
\hline 2 & $\begin{array}{l}\text { Pertambangan } \\
\text { dan } \\
\text { Penggalian }\end{array}$ & $\begin{array}{c}1.429 . \\
949\end{array}$ & $\begin{array}{c}1.481 .0 \\
32\end{array}$ & $\begin{array}{c}1.435 .7 \\
79\end{array}$ & $\begin{array}{c}1.432 .5 \\
65\end{array}$ & $\begin{array}{l}1.500 .6 \\
73\end{array}$ & $\begin{array}{c}1.489 .5 \\
98\end{array}$ & $\begin{array}{c}1.493 .9 \\
55\end{array}$ & $\begin{array}{c}1.569 .1 \\
13\end{array}$ \\
\hline 3 & $\begin{array}{l}\text { Industri } \\
\text { Pengolahan }\end{array}$ & $\begin{array}{c}153.96 \\
9\end{array}$ & $\begin{array}{c}161.52 \\
0\end{array}$ & 168.179 & 174.584 & 173.964 & 194.316 & 220.342 & 243.250 \\
\hline 4 & $\begin{array}{l}\text { Pengadaan } \\
\text { Listrik, Gas }\end{array}$ & 1.551 & 1.820 & 2.027 & 2.196 & 2.538 & 2.777 & 3.030 & 3.209 \\
\hline 5 & $\begin{array}{l}\text { Pengadaan } \\
\text { Air, } \\
\text { Pengelolaan } \\
\text { Sampah, } \\
\text { Limbah, dan } \\
\text { Daur Ulang }\end{array}$ & 215 & 446 & 568 & 637 & 709 & 844 & 913 & 1.008 \\
\hline 6 & Konstruksi & $\begin{array}{c}259.85 \\
1\end{array}$ & $\begin{array}{c}285.51 \\
4\end{array}$ & 309.313 & 330.327 & 346.257 & 360.731 & 392.156 & 431.058 \\
\hline 7 & $\begin{array}{l}\text { Perdagangan } \\
\text { Besar dan } \\
\text { Eceran; dan } \\
\text { Reparasi } \\
\text { Mobil dan } \\
\text { Sepeda Motor }\end{array}$ & $\begin{array}{c}401.42 \\
8\end{array}$ & $\begin{array}{c}428.21 \\
1\end{array}$ & 449.320 & 470.730 & 485.553 & 502.322 & 537.183 & 596.132 \\
\hline 8 & $\begin{array}{l}\text { Transportasi } \\
\text { dan } \\
\text { Pergudangan }\end{array}$ & 26.951 & 27.970 & 30.536 & 32.899 & 35.106 & 37.251 & 39.610 & 42.847 \\
\hline 9 & $\begin{array}{l}\text { Penyediaan } \\
\text { Akomodasi } \\
\text { dan Makan } \\
\text { Minum }\end{array}$ & 61.745 & 67.698 & 74.017 & 78.981 & 83.460 & 88.682 & 95.884 & 104.624 \\
\hline 10 & $\begin{array}{l}\text { Informasi dan } \\
\text { Komunikasi }\end{array}$ & 20.781 & 22.488 & 24.131 & 25.519 & 27.273 & 28.912 & 31.449 & 34.208 \\
\hline
\end{tabular}




\begin{tabular}{|c|c|c|c|c|c|c|c|c|c|}
\hline 11 & $\begin{array}{l}\text { Jasa Keuangan } \\
\text { dan Asuransi }\end{array}$ & 15.127 & 17.678 & 20.050 & 21.786 & 23.687 & 25.699 & 27.329 & 28.015 \\
\hline 12 & Real Estate & $\begin{array}{c}112.19 \\
7\end{array}$ & $\begin{array}{c}120.21 \\
1\end{array}$ & 134.770 & 144.346 & 154.435 & 157.770 & 164.256 & 174.244 \\
\hline 13 & $\begin{array}{l}\text { Jasa } \\
\text { Perusahaan }\end{array}$ & 4.823 & 5.290 & 5.730 & 6.073 & 6.431 & 6.612 & 6.681 & 7.195 \\
\hline 14 & $\begin{array}{l}\text { Administrasi } \\
\text { Pemerintah, } \\
\text { Pertahanan, } \\
\text { dan Jaminan } \\
\text { Sosial Wajib }\end{array}$ & $\begin{array}{c}168.36 \\
1\end{array}$ & $\begin{array}{c}188.30 \\
6\end{array}$ & 196.281 & 215.477 & 232.175 & 251.020 & 268.231 & 285.838 \\
\hline 15 & $\begin{array}{l}\text { Jasa } \\
\text { Pendidikan }\end{array}$ & 75.501 & 82.215 & 89.072 & 96.069 & 103.679 & 112.332 & 122.263 & 128.679 \\
\hline 16 & $\begin{array}{l}\text { Rasa } \\
\text { Kesehatan dan } \\
\text { Kegiatan } \\
\text { Sosial }\end{array}$ & 21.571 & 23.303 & 24.779 & 26.140 & 27.856 & 30.010 & 31.570 & 34.416 \\
\hline 17 & Jasa lainnya & 10.867 & 11.996 & 13.147 & 13.927 & 14.857 & 15.936 & 17.622 & 18.859 \\
\hline $\begin{array}{r}\text { Prc } \\
\text { R }\end{array}$ & $\begin{array}{l}\text { duk Domestik } \\
\text { egional Bruto }\end{array}$ & $\begin{array}{c}4169 \\
513\end{array}$ & $\begin{array}{c}4.169 .5 \\
13\end{array}$ & $\begin{array}{c}4.437 .3 \\
23\end{array}$ & $\begin{array}{c}4.646 .0 \\
26\end{array}$ & $\begin{array}{c}4.852 .9 \\
74\end{array}$ & $\begin{array}{c}5.068 .2 \\
67\end{array}$ & $\begin{array}{c}5.284 .6 \\
42\end{array}$ & $\begin{array}{c}5.511 .7 \\
72\end{array}$ \\
\hline
\end{tabular}

Sumber : BPS Bangka Selatan, 2010-2017

Di dalam penelitian ini Selain PDRB KabupatenBangka Selatan sebagai salah satu tolak ukur, PDRB Bangaka Belitung juga gunakan untuk perhitungan nilai LQ. Pada tabel 2, PDRB Bangka Belitung pada kurun waktu 8 tahun terakhir juga mengalami perkembangan yg sama yaitu terjadi kenaikan di tahun 2017. 
Tabel 4.2 PDRB Provinsi Bangka Belitung Atas Dasar Harga Konstan (ADHK)

\subsubsection{Analisis Potensi Sektor Lapangan Usaha di Kabupaten Bangka Selatan}

\begin{tabular}{|c|c|c|c|c|c|c|c|c|c|}
\hline \multirow{2}{*}{ No. } & \multirow{2}{*}{ Sektor } & \multicolumn{8}{|c|}{ Dalam Juta Rupiah } \\
\hline & & 2010 & 2011 & 2012 & 2013 & 2014 & 2015 & 2016 & 2017 \\
\hline 1 & $\begin{array}{l}\text { Pertanian, } \\
\text { Kehutanan, dan } \\
\text { Perikanan }\end{array}$ & 6.097 .691 & 6.642 .800 & 7.072 .887 & 7.557 .660 & 8.254 .342 & 8.743 .508 & 9.116 .853 & 9.083 .781 \\
\hline 2 & $\begin{array}{l}\text { Pertambangan } \\
\text { dan Penggalian }\end{array}$ & 6.077 .439 & 6.263 .560 & 6.270 .079 & 6.230 .237 & 6.354 .052 & 6.458 .090 & 6.491 .063 & 6.633 .039 \\
\hline 3 & $\begin{array}{l}\text { Industri } \\
\text { Pengolahan }\end{array}$ & 9.174 .668 & 9.515 .757 & 9.804 .878 & 10.143 .284 & 10.270 .405 & 10.400 .640 & 10.688 .366 & 11.363 .050 \\
\hline 4 & $\begin{array}{l}\text { Pengadaan } \\
\text { Listrik dan Gas }\end{array}$ & 24.117 & 27.304 & 30.087 & 31.532 & 35.623 & 38.904 & 43.742 & 45.864 \\
\hline 5 & $\begin{array}{l}\text { Pengadaan Air, } \\
\text { Pengelolaan } \\
\text { Sampah, } \\
\text { Limbah dan } \\
\text { Daur Ulang }\end{array}$ & 6.160 & 6.641 & 7.022 & 7.316 & 7.678 & 8.119 & 8.567 & 9.406 \\
\hline 6 & Konstruksi & 2.531 .855 & 2.758 .267 & 3.133 .802 & 3.414 .740 & 3.552 .379 & 3.760 .126 & 4.021 .606 & 4.252 .102 \\
\hline 7 & $\begin{array}{l}\text { Perdagangan } \\
\text { Besar dan } \\
\text { Eceran; } \\
\text { Reparasi Mobil } \\
\text { dan Sepeda } \\
\text { Motor }\end{array}$ & 4.720 .707 & 5.162 .127 & 5.528 .137 & 5.846 .612 & 6.139 .455 & 6.402 .146 & 6.727 .660 & 7.259 .823 \\
\hline 8 & $\begin{array}{l}\text { Transportasi } \\
\text { dan } \\
\text { Pergudangan } \\
\text { Penyediaan }\end{array}$ & 1.161 .976 & 1.272 .729 & 1.384 .756 & 1.484 .808 & 1.570 .780 & 1.662 .270 & 1.752 .264 & 1.892 .222 \\
\hline 9 & $\begin{array}{l}\text { Akomodasi } \\
\text { dan Makan } \\
\text { Minum }\end{array}$ & 742.772 & 808.357 & 870.984 & 930.987 & 1.000 .562 & 1.034 .807 & 1.086 .468 & 1.136 .528 \\
\hline 10 & $\begin{array}{l}\text { Informasi dan } \\
\text { Komunikasi }\end{array}$ & 578.288 & 625.202 & 679.225 & 740.153 & 790.872 & 848.950 & 926.926 & 1.002 .849 \\
\hline 11 & $\begin{array}{l}\text { Jasa Keuangan } \\
\text { dan Asuransi }\end{array}$ & 499.641 & 581.499 & 624.228 & 728.335 & 766.645 & 807.921 & 859.976 & 881.268 \\
\hline 12 & Real Estate & 987.085 & 1.098 .404 & 1.215 .662 & 1.312 .637 & 1.403 .929 & 1.441 .959 & 1.494 .832 & 1.572 .538 \\
\hline 13 & $\begin{array}{l}\text { Jasa } \\
\text { Perusahaan } \\
\text { Administrasi }\end{array}$ & 85.435 & 93.877 & 101.223 & 108.110 & 115.692 & 120.342 & 120.419 & 127.462 \\
\hline 14 & $\begin{array}{l}\text { Pemerintahan, } \\
\text { Pertahanan dan } \\
\text { Jaminan Sosial } \\
\text { Wajib }\end{array}$ & 1.597 .081 & 1.778 .004 & 1.873 .016 & 2.014 .417 & 2.149 .841 & 2.337 .095 & 2.478 .742 & 2.604 .173 \\
\hline 15 & $\begin{array}{l}\text { Jasa } \\
\text { Pendidikan }\end{array}$ & 706.120 & 755.509 & 821.706 & 903.742 & 964.923 & 1.059 .002 & 1.139 .349 & 1.183 .335 \\
\hline 16 & $\begin{array}{l}\text { Jasa Kesehatan } \\
\text { dan Kegiatan } \\
\text { Sosial }\end{array}$ & 360.425 & 397.499 & 442.949 & 475.323 & 500.550 & 533.850 & 559.579 & 605.385 \\
\hline 17 & Jasa lainnya & 210.443 & 226.453 & 244.264 & 260.965 & 281.710 & 304.577 & 334.409 & 354.926 \\
\hline & $\begin{array}{l}\text { duk Domestik } \\
\text { gional Bruto }\end{array}$ & 35.561 .904 & 38.013.990 & 40.104 .906 & 42.190 .857 & 44.159 .440 & 45.962 .304 & 47.850 .821 & 50.007 .751 \\
\hline
\end{tabular}

Sumber: BPS Bangka Belitung, 2010 - 2017 
Hasil perhitungan Location Quotient (LQ) Kabupaten Bangka Selatan selama 8 tahun (2010-2017) selengkapnya dilihat pada tabel 3.

Tabel 4.3 Hasil Nilai Rata-Rata Location Quotientdi Kabupaten Bangka Selatan

\begin{tabular}{|c|c|c|c|c|c|c|c|c|c|c|}
\hline No & Sektor & $\begin{array}{l}201 \\
0\end{array}$ & $\begin{array}{l}201 \\
1\end{array}$ & $\begin{array}{l}201 \\
2 \\
\end{array}$ & $\begin{array}{l}201 \\
3 \\
\end{array}$ & $\begin{array}{l}201 \\
4 \\
\end{array}$ & $\begin{array}{l}201 \\
5 \\
\end{array}$ & $\begin{array}{l}201 \\
6 \\
\end{array}$ & $\begin{array}{l}201 \\
7 \\
\end{array}$ & $\begin{array}{l}\text { RATA- } \\
\text { RATA }\end{array}$ \\
\hline 1 & $\begin{array}{l}\text { Pertanian, } \\
\text { Kehutanan, } \\
\text { dan } \\
\text { Perikanan }\end{array}$ & $\begin{array}{c}1,9 \\
6\end{array}$ & $\begin{array}{c}1,9 \\
5\end{array}$ & $\begin{array}{c}2,0 \\
3\end{array}$ & $\begin{array}{c}2,0 \\
5\end{array}$ & $\begin{array}{c}1,9 \\
5\end{array}$ & $\begin{array}{c}1,9 \\
7\end{array}$ & $\begin{array}{c}1,9 \\
6\end{array}$ & $\begin{array}{c}1,9 \\
6\end{array}$ & 1,98 \\
\hline 2 & $\begin{array}{l}\text { Pertambang } \\
\text { an dan } \\
\text { Penggalian }\end{array}$ & $\begin{array}{c}2,0 \\
0\end{array}$ & $\begin{array}{c}2,0 \\
2\end{array}$ & $\begin{array}{c}1,9 \\
7\end{array}$ & $\begin{array}{c}2,0 \\
0\end{array}$ & $\begin{array}{c}2,0 \\
5\end{array}$ & $\begin{array}{c}2,0 \\
0\end{array}$ & $\begin{array}{c}2,0 \\
0\end{array}$ & $\begin{array}{c}2,0 \\
5\end{array}$ & 2,01 \\
\hline 3 & $\begin{array}{l}\text { Industri } \\
\text { Pengolahan }\end{array}$ & $\begin{array}{c}0,1 \\
4\end{array}$ & $\begin{array}{c}0,1 \\
4\end{array}$ & $\begin{array}{c}0,1 \\
5\end{array}$ & $\begin{array}{c}0,1 \\
5\end{array}$ & $\begin{array}{c}0,1 \\
5\end{array}$ & $\begin{array}{c}0,1 \\
6\end{array}$ & $\begin{array}{c}0,1 \\
8\end{array}$ & $\begin{array}{c}0,1 \\
8\end{array}$ & 0,16 \\
\hline 4 & $\begin{array}{l}\text { Pengadaan } \\
\text { Listrik dan } \\
\text { Gas }\end{array}$ & $\begin{array}{c}0,5 \\
5\end{array}$ & $\begin{array}{c}0,5 \\
7\end{array}$ & $\begin{array}{c}0,5 \\
8\end{array}$ & $\begin{array}{c}0,6 \\
0\end{array}$ & $\begin{array}{c}0,6 \\
2\end{array}$ & $\begin{array}{c}0,6 \\
2\end{array}$ & $\begin{array}{c}0,6 \\
0\end{array}$ & $\begin{array}{c}0,6 \\
1\end{array}$ & 0,59 \\
\hline 5 & $\begin{array}{l}\text { Pengadaan } \\
\text { Air, } \\
\text { Pengelolaan } \\
\text { Sampah, } \\
\text { Limbah dan } \\
\text { Daur Ulang }\end{array}$ & $\begin{array}{c}0,3 \\
0\end{array}$ & $\begin{array}{c}0,5 \\
7\end{array}$ & $\begin{array}{c}0,7 \\
0\end{array}$ & $\begin{array}{c}0,7 \\
5\end{array}$ & $\begin{array}{c}0,8 \\
0\end{array}$ & $\begin{array}{c}0,9 \\
0\end{array}$ & $\begin{array}{c}0,9 \\
2\end{array}$ & $\begin{array}{c}0,9 \\
3\end{array}$ & 0,73 \\
\hline 6 & Konstruksi & $\begin{array}{c}0,8 \\
7\end{array}$ & $\begin{array}{c}0,8 \\
8\end{array}$ & $\begin{array}{c}0,8 \\
5\end{array}$ & $\begin{array}{c}0,8 \\
4\end{array}$ & $\begin{array}{c}0,8 \\
5\end{array}$ & $\begin{array}{c}0,8 \\
3\end{array}$ & $\begin{array}{c}0,8 \\
4\end{array}$ & $\begin{array}{c}0,8 \\
8\end{array}$ & 0,86 \\
\hline 7 & $\begin{array}{l}\text { Perdagangan } \\
\text { Besar dan } \\
\text { Eceran; } \\
\text { Reparasi } \\
\text { Mobil dan } \\
\text { Sepeda } \\
\text { Motor }\end{array}$ & $\begin{array}{c}0,7 \\
2\end{array}$ & $\begin{array}{c}0,7 \\
1\end{array}$ & $\begin{array}{c}0,7 \\
0\end{array}$ & $\begin{array}{c}0,7 \\
0\end{array}$ & $\begin{array}{c}0,6 \\
9\end{array}$ & $\begin{array}{c}0,6 \\
8\end{array}$ & $\begin{array}{c}0,6 \\
9\end{array}$ & $\begin{array}{c}0,7 \\
1\end{array}$ & 0,70 \\
\hline 8 & $\begin{array}{l}\text { Transportasi } \\
\text { dan } \\
\text { Pergudangan } \\
\text { Penyediaan }\end{array}$ & $\begin{array}{c}0,2 \\
0\end{array}$ & $\begin{array}{c}0,1 \\
9\end{array}$ & $\begin{array}{c}0,1 \\
9\end{array}$ & $\begin{array}{c}0,1 \\
9\end{array}$ & $\begin{array}{c}0,1 \\
9\end{array}$ & $\begin{array}{c}0,1 \\
9\end{array}$ & $\begin{array}{c}0,1 \\
9\end{array}$ & $\begin{array}{c}0,1 \\
9\end{array}$ & 0,19 \\
\hline 9 & $\begin{array}{l}\text { Akomodasi } \\
\text { dan Makan } \\
\text { Minum }\end{array}$ & $\begin{array}{c}0,7 \\
1\end{array}$ & $\begin{array}{c}0,7 \\
2\end{array}$ & $\begin{array}{c}0,7 \\
3\end{array}$ & $\begin{array}{c}0,7 \\
4\end{array}$ & $\begin{array}{c}0,7 \\
2\end{array}$ & $\begin{array}{c}0,7 \\
4\end{array}$ & $\begin{array}{c}0,7 \\
6\end{array}$ & $\begin{array}{c}0,8 \\
0\end{array}$ & 0,74 \\
\hline 10 & $\begin{array}{l}\text { Informasi } \\
\text { dan } \\
\text { Komunikasi }\end{array}$ & $\begin{array}{c}0,3 \\
0\end{array}$ & $\begin{array}{c}0,3 \\
0\end{array}$ & $\begin{array}{c}0,3 \\
0\end{array}$ & $\begin{array}{c}0,3 \\
0\end{array}$ & $\begin{array}{c}0,3 \\
0\end{array}$ & $\begin{array}{c}0,2 \\
9\end{array}$ & $\begin{array}{c}0,2 \\
9\end{array}$ & $\begin{array}{c}0,2 \\
9\end{array}$ & 0,30 \\
\hline 11 & $\begin{array}{l}\text { Jasa } \\
\text { Keuangan } \\
\text { dan Asuransi }\end{array}$ & $\begin{array}{c}0,2 \\
6\end{array}$ & $\begin{array}{c}0,2 \\
6\end{array}$ & $\begin{array}{c}0,2 \\
8\end{array}$ & $\begin{array}{c}0,2 \\
6\end{array}$ & $\begin{array}{c}0,2 \\
7\end{array}$ & $\begin{array}{c}0,2 \\
7\end{array}$ & $\begin{array}{c}0,2 \\
7\end{array}$ & $\begin{array}{c}0,2 \\
7\end{array}$ & 0,27 \\
\hline 12 & Real Estate & $\begin{array}{c}0,9 \\
7\end{array}$ & $\begin{array}{c}0,9 \\
4\end{array}$ & $\begin{array}{c}0,9 \\
5\end{array}$ & $\begin{array}{c}0,9 \\
5\end{array}$ & $\begin{array}{c}0,9 \\
5\end{array}$ & $\begin{array}{c}0,9 \\
5\end{array}$ & $\begin{array}{c}0,9 \\
5\end{array}$ & $\begin{array}{c}0,9 \\
6\end{array}$ & 0,95 \\
\hline
\end{tabular}




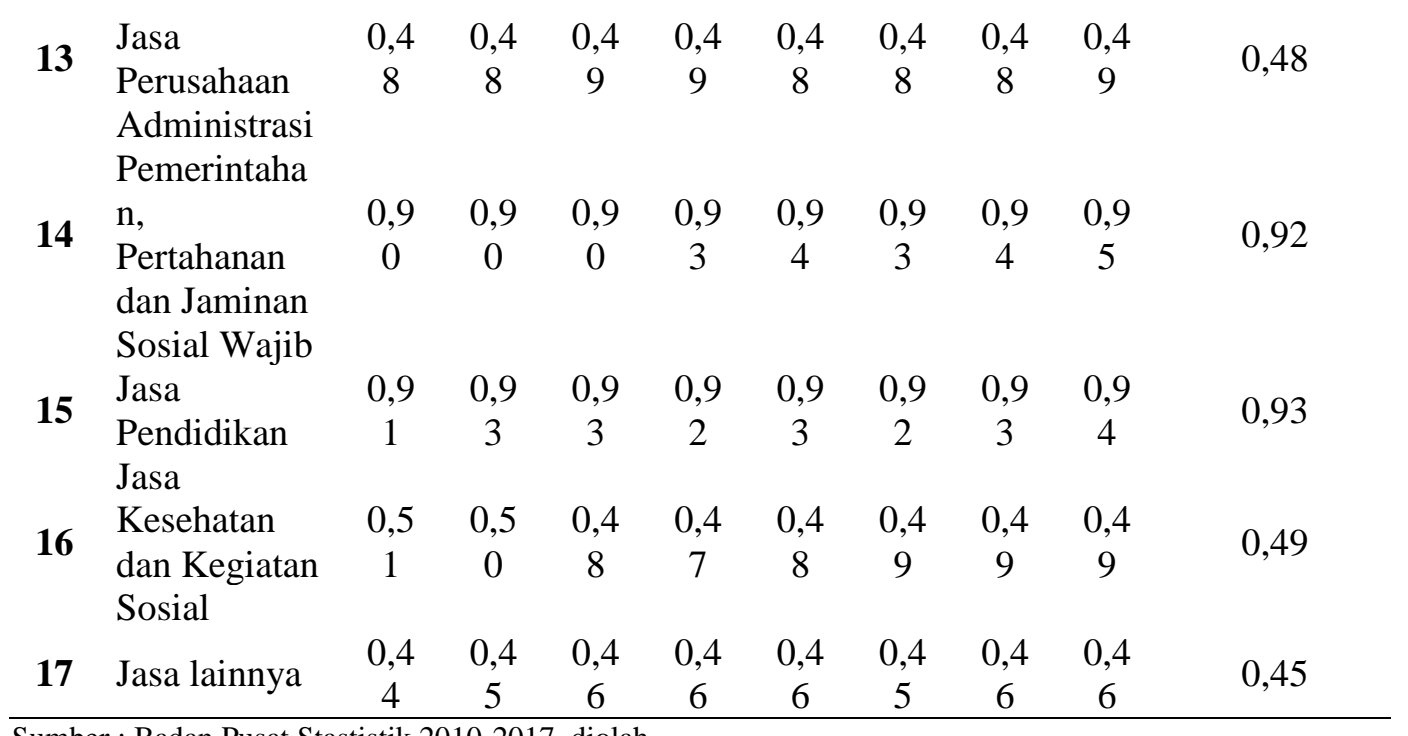

Sumber : Badan Pusat Stastistik 2010-2017, diolah

Berdasarkan tabel 3,dari 17 sektor yang ada di Kabupaten Bangka Selatanterdapat 2 sektoryang berpotensi, yaitu sektor pertanian, kehutanan, dan perikanandengan hasil ratarata LQ sebesar 1,98dan sektor pertambangan dan penggalian dengan hasil rata-rata LQ sebesar 2,01merupakan sektor unggulan di Kabupaten Bangka Selatan sesuai dengan penilaian LQ, yang dimana Sektor pertamabangan dan pengalian lebih unggul dari pada sektor pertanian, kehutanan dan perikankarna masihbanyak masyarakat mencari penghasilan melalui sektor pertambangan dan penggalian dari pada sektor pertanian, kehutanan, dan perikanan untuk memenuhi kebutuhan dan menyumbang pendapatan PDRB di Kabupaten Bangka selatan. Namun sektor pertambangan dan penggalian memiliki dampak dampak negatif yang besar dari pada sektor pertania, kehutanan, dan perikanan. Karena sektor pertambangan dan penggalian merusak ekosistem sumber daya alam dalam jangkan panjang. misalkan menipisnya daratan akibat penambangan dan pengalian yang sulit di pulihkan kembali seperti semula sehingga mengakibatkan sempitnya lahan daratan. Dan selnjutnya Untuk mengetahui seberapa besar di ekpor ke luar daerah bangka selatan dan seberapa besar untuk di konsumsi dalam negeri dapat di lihat di tabel 4 sebagai berikut:

Tabel 4.4 Nilai LQ Yang Akan Di Ekpor Dan Di Konsumsi Dalam Negeri Kabupaten Bangka Selatan

\begin{tabular}{ccc}
\hline Tahun & $\begin{array}{c}\text { Pertanian, Kehutanan, dan } \\
\text { Perikanan }\end{array}$ & $\begin{array}{c}\text { Pertambangan dan } \\
\text { Penggalian }\end{array}$ \\
\hline 2010 & 1,96 & 2,00 \\
2011 & 1,95 & 2,02 \\
2012 & 2,03 & 1,97 \\
2013 & 2,04 & 2,00 \\
2014 & 1,95 & 2,06 \\
2015 & 1,97 & 2,00 \\
2016 & 1,96 & 2,00 \\
2017 & 1,97 & 2,05 \\
\hline
\end{tabular}

\begin{tabular}{lll}
\hline Rata-Rata & 1,98 & 2,01 \\
\hline
\end{tabular}




\begin{tabular}{ccc}
\hline Ekpor & $49,5 \%$ & $50,4 \%$ \\
\hline $\begin{array}{c}\text { Konsumsi } \\
\text { Dalam Negeri }\end{array}$ & $50,5 \%$ & $49,6 \%$ \\
\hline
\end{tabular}

Sumber : Badan Pusat Stastistik 2010-2017, diolah

Dari Sektor pertambangan dan pengaliandi dapatlah nilai rata-rata LQ seesar(1,01) artinya secara teoritis sebanyak 50,4 persen hasilnya dapat diekspor dan sisanya 49,4 persen dapat dikonsumsi di dalam negeri yang akan menjadi penyumbang pendapatan PDRB dari sektor Pertambangan dan Penggalian di Kabupaten Bangka selatan. Selanjutnya dariSektor pertanian, kehutanan dan perikanandi dapatlah nilai rata-rata LQ sebesar $(1,98)$ artinya secara teoritis sebanyak 49,5 persen hasilnya dapat diekspor dan sisanya 50,5 persen dapat dikonsumsi dalam negeri yang akan menjadi penyumbang pendapatan PDRB dari sektor pertania, kehutanan, dan perikanan di Kabupaten Bangka Selatan yang secara tidaak langsung akan meningkatkan pertumbuhan perekonmian di Kabupaten Bangka Selatan

\section{KESIMPULAN}

Hasil penelitian menyimpulkan bahwa dari 17 sektor yang ada di Kabupaten Bangka Selatan terdapat 2 sektor yang merupakan sektor potensidenganmemiliki nilairata-rata LQ di atas 1 yaitu sektor pertambangan dan penggalian sebesar $(2,01)$ serta sektor pertanian, kehutanan dan perikanan sebesar $(1,98)$. Hal ini mengidentifikasikan bahwa kedua sektor tersebut merupakan sektor yang dapat dikembangkan dalam rangka meningkatkan Pendapatan Domenstik Regional Bruto di Kabupaten Bangka Selatan. Dilihat dari segi konsumsinya kedua sektor tersebut hasilnya dapat di ekpor dan sebagian lagi untuk di konsumsi dalam Negeri. Dari hasil perhitungan nilai ekporSektor pertambangan dan penggalian sebesar 50,4 persen dan sisnya di konsumsi dalam negeri sedangkan hasil perhitungan nilai ekpor sektor pertanian, kehutanan, dan perikanan sebesar 49,5 persen dan sisanya di konsumsi dalam negeri.

\section{UCAPAN TERIMA KASIH}

Penulis menyadari masih memiliki kekurangan terutama disebabkan akan kurangnya pengetahuan dan sumber acuan yang berkenaan dengan Kuliah Lapangan, namun berkat bimbingan dan bantuan dari berbagai pihak akhirnya laporan kuliah lapangan ini dapat terselesaikan walaupun masih terdapat kekurangan di dalamnya. Penulis juga mengucapkan terimakasih kepada :

1. Bapak/Ibu sebagai dosen pembimbing dan selaku orang tua penulis yang telah memberikan dukungan, doa dan restu kepada penulis dalam menyelesaikan Kuliah Lapangan ini.

2. Ibu Dr. Hj. Devi Valeriani, S.E., M.Si selaku ketua Program Ekonomi Pembangunan Universitas Bangka Belitung.

3. Ibu Ayu Wulandari, SE.,M.Si. selaku pembimbing I yang telah telah memberikan saran dan masukan dalam pembuatan laporan kuliah lapangan.

4. Ibu Etania Harum Yonanda, SST,M.Ec.Dev. selaku pembimbing II yang telah bersedia membantu dan membimbing pada kegiatan kuliah lapangan di kantor BPS Kota Pangkalpinang.

5. Semua pihak di Badan Pusat Statistik di Kota Pangkalpinang Provinsi Bangka Belitung yang telah berkenan memberikan izin untuk melakukan kuliah lapangan.

6. Kedua orang tua tercinta saya bapak Purwanto dan Ibu Susi yang selalu mendoakan, memberikan motivasi dan memberikan dukungan sepenuh hati. 
7. Kepada seluruh teman-teman 16 IE 1 khususnya rekan magang di Badan Pusat Stastistik Kota Pangkalpinang Arsi Wahyuni, Indri Kurniawan dan Ihsan doni.

\section{REFERENSI}

\section{Artikel}

Hendayana. 2016. Aplikasi Metode Location Quotient Dalam Penentuan Komoditas Unggulan Nasional. Bogor:

Indrawati. 2009. Analisis Dampak Sektor Unggulan Terhadap Perekonomian Kota Pangkalpinang. fakultas Ekonomi dan Manajemen.Institut Pertanian. Bogor.

Moineddin, Beyene, dan Boyl. 2003. On the Location Quotient Confidence Interval. Vol. 35, No. 3 July 2003.

Ronykur. 2014. Aplikasi Location Quotient (LQ) Sebagai Metode Penentuan Komoditas Palawija Unggulan Di Kabupaten Nganjuk.Vol. 1 No. 2 Juli 2014.

\section{For an organizational or government report or document with no author}

BankIndonesia. 2018. Metadata. di akses: https://www.bi.go.id/idstatistik/metadata/sekda/8PDRBSEKDA1.pdf. November 2018

Fajarwati.2015.Provinsi Kepulauan Bangka Belitung dalam angka 2015. BPS Provinsi Kepulauan Bangka Belitung

Sitorus.2018.Provinsi Kepulauan Bangka Belitung Dalam Angka 2018. BPS Pangkalpinang.

Taufik.2015.Kabupaten Bangka Selatan Dalam Angka 2015. Badan Pusat Statistik, Pangkalpinang

Zainubi.2018.Kabupaten Bangka Selatan Dalam Angka 2018. Badan Pusat Statistik, Pangkalpinang 